OLD WORLD

SOUTH AFRICA

\section{Rute for the Age}

by a South African Correspondent

ThE Joint Council of Scientific Societies in 1969 undertook a survey on the distribution, qualifications and income of scientists in South Africa. The survey was done by Dr A. P. Burger, director of the National Research Institute for Mathematical Sciences, Council for Scientific and Industrial Research, and his results have now been published (J.C.S.S. Survey of Scientists, 1969, obtainable from the Secretariat, P.O. Box 61019, Marshalltown, Transvaal). Since the start of the survey, salaries in all occupations including science have been substantially increased. The maximum salary for university professors, for example, has been increased from $\mathbf{R} 7,200$ to $\mathbf{R} 9,900$ ( $£=\mathbf{R} 1.71$ ). Virtually all salaries have been adjusted to roughly the same extent, however, so that while the data obtained in the survey are probably outdated, the findings are still largely valid.

Predictably, scientists in the public sector were more poorly paid than those in the private sector, while both groups earned considerably less than selfemployed members of professions operating for their own gain. As shown also by Masson (S. Afr. J. Sci., 65, 329; 1969), biologists, possibly owing to their negligible market value in the private sector, were more poorly paid than their colleagues in the mathematical and physical sciences, even though the biologists included a larger proportion of highly trained scientists. School teachers were conspicuously worse off than other groups, even in the public sector. In addition there were fewer teachers between 30 and 45 years of age than above 45 years, suggesting that the poor salary conditions in teaching have been responsible for a regrettably low influx into this profession and/or early loss of young teachers to other professions.

Fortunately, the salary improvements in the past two years have been perhaps more favourable for teachers than for other employees of the public sector, so that the present picture is more encouraging.

A few big employers in the public sector employed 51 per cent of government and semi-government scientists. These employers paid distinctly poorer salaries than the smaller employers in this sector. Government corporations, on the other hand, paid very well, their salaries corresponding to those in the private sector. While higher qualifications, on the whole, led to better salaries, graduates with honours degrees were not noticeably better paid than those with bachelor's degrees.
Recently, concern in the public sector has been mainly for the more junior salary levels and the fact that too few young scientists were being recruited because of the unattractive immediate financial future facing them. The survey shows, however, that concern for salaries of senior scientists is justified. It appears that not only did scientists in the private sector earn considerably more (scientists earning $\mathbf{R} 8,000$ per year in government service could expect $\mathrm{R} 14,000$ in the private sector), but salaries levelled off more rapidly in the public sector than the private; in the latter, the average scientist at 57 earned roughly $\mathrm{R} 3,000$ more than his colleague of 37 , while in the former the salary difference was only R800. In the teaching profession the difference was even smaller, only R160 per year. The spread of incomes within each age group was much smaller in the public than in the private sector, and with it "the opportunity to distinguish between staff of superior and lesser merit".

\section{SCIENTIFIC INFORMATION UNESCO and ICSU Unisist}

THE joint committee set up in 1967 by UNESCO and the International Council of Scientific Institutions (ICSU) to study the problems of scientific information has now reported. The committee, the moving spirit in which has been Professor Harrison Brown, foreign secretary of the United States National Academy of Sciences, is known formally as the Central Committee on the Feasibility of a World Science Information System, translated by the acronym Unisist. The report which has been prepared will be the raw material for an intergovernmental conference in October this year at which UNESCO hopes that there will be established a world science information system.

The synopsis which accompanies the full report says that the need to set up an integrated information system has been occasioned by a qualitative change in the character of science in the past twenty years. One practical result, the report says, is that newly emergent interdisciplinary fields have created the need for the repackaging of scientific information in new forms, often ephemeral. The result is that information services can no longer be left in the hands of scientists, librarians and other specialists. The Unisist committee has come out strongly for a national organization in every country with responsibility for the processing and

\title{
MOLECULAR BIOLOGY MRC Funds Still Flow
}

IN spite of reports last week that research at the Medical Research Council Laboratory of Molecular Biology in Cambridge is in jeopardy, there seems to be no immediate danger that it will be cut back. Although there are to be economies on expenditure for consumables, no research will be dropped nor will the start of any new programme be delayed.

The reduction in funds for the research councils which was announced last September has meant that the rate of increase of income for the councils will be less than had been planned. The budget of the Medical Research Council as a whole has increased steadily during the past five years. The allocation for the current financial year is $£ 23$ million, an increase of 17 per cent compared with that of $£ 19.7$ million last year. The overall cut is being passed on to the research units, although newly established units have usually been treated a little more generously than simple proportion would dictate. The MRC Laboratory of Molecular Biology continues to receive more than three per cent of the MRC budget-3.43 per cent this year, compared with 3.17 per cent last year.

These allocations do not, however, take account of inflation, which has eroded most of the increases. In terms of spending power, most MRC units will be in much the same position this year as they were last year. There will, however, be a little more flexibility, for it has been agreed that the directors of individual units will be able to decide for themselves how their allocations will be spent. This means, for example, that a decision could be made to leave a post vacant and instead to purchase equipment.

MRC Molecular Biology (supply estimates)

\begin{tabular}{|c|c|c|c|c|c|}
\hline & & & & & $\begin{array}{l}\text { Per cent } \\
\text { spent on }\end{array}$ \\
\hline Year & Recurrent & Capital & Total & MRC grant-in-aid & MRC mol. biol. \\
\hline $1971-1972$ & 0.71 & 0.07 & 0.78 & 23.0 & 3.43 \\
\hline $1970-1971$ & 0.52 & 0.10 & 0.62 & 19.7 & 3.17 \\
\hline $1969-1970$ & 0.38 & 0.15 & 0.53 & 17.1 & 3.12 \\
\hline $1968-1969$ & 0.32 & 0.22 & 0.54 & 15.3 & 3.57 \\
\hline $1967-1968$ & 0.29 & 0.23 & 0.52 & 14.2 & 3.69 \\
\hline
\end{tabular}

